\title{
Edible Oil Production in Egypt: An Overview
}

\author{
Mona El-Hamidi \\ Fats and Oils Department, National Research Centre, 33 Buhouth St. Dokki, Giza, Egypt \\ Email: mona32001@hotmail.com \\ Ferial A. Zaher \\ Fats and Oils Department, National Research Centre, 33 Buhouth St. Dokki, Giza, Egypt \\ Email: zaher_ferial@yahoo.com \\ Atteia Shaaban \\ Chamber of Food Industry; Federation of Egyptian Industry, Cairo, Egypt \\ Email: abshaaban88@gmail.com
}

Received: 25 Oct. 2020 / Accepted 10 Dec. 2020 / Publication date: 20 Dec. 2020

\begin{abstract}
This article throws a light on the current situation of edible oil industrial sector in Egypt. The existing wide gap between the consumption rate of edible oil in Egypt and the rate of edible oil production from local oilseed is discussed. The type of edible oils imported annually to cover this gap and their quantities are reported. Processing steps for edible oil production from oilseed have been briefly illustrated. Important parameters for successful edible oil industry have been also reported and discussed. The companies already established in Egypt for oilseed extraction are outlined whether they belong to the public or private sectors as well as the companies which are still under construction. These companies have been identified according to their production capacity as well as the technology adopted in oilseed extraction.
\end{abstract}

Keywords: Edible oil, imported edible oil, processing, production.

\section{Introduction}

Cottonseed oil was the first edible oil extracted worldwide from oilseeds whereby it was extracted for the first time in USA in 1768. Due to the progress in cotton ginning industry and the increase of cottonseed production as a byproduct of this industry, the production of a crude oil from cottonseed has been established in USA in 1799 (Jennings, 2010). Production of refined cottonseed oil suitable for human consumption started in France in 1850 and its technology has been then exported back to the United States.

In Egypt, this industry has been started since 1888 whereby cottonseed oil was extracted from its oilseed by hydraulic pressing in Alexandria and Kafr El-Zayat cities. In 1895, about one thousand ton of cottonseed oil has been produced and its production rate each year have been changed over the years in accordance to the annual production of cotton crop cultivated in Egypt. Figure 1 shows the rate of cottonseed oil production since 1969 up to 2019 (United States Department of Agriculture, 2020). According to that Figure, it is quite clear that the production of cottonseed oil in Egypt has been decreased greatly over the years from 1969 whereby it was 125 thousand tons oil in 1969 to 10 thousand tons only in 2019.

\section{Consumption rate of edible oil in Egypt}

In view of the rapid increase in the population in Egypt whereby Egypt's population grows by approximately 1.5 million people each year and in view of the fact that the consumption rate per capita of edible oils has been progressively increased in recent years, the consumption rate of edible oil has been greatly increased (El-Hamidi and Zaher, 2018). Currently, Egypt consumes about 2.5 million tons of edible oils annually. Only, about 48.5 thousand tons of this quantity is produced by oilseed extraction in local extraction plants. About half of this quantity is produced mainly from cottonseed produced as a byproduct of cotton ginning industry. The other half is extracted from local sunflower oilseed in addition to imported soybean as listed in Table 1 (Aswaq Financial Co., 2018). The total quantity of oil produced in Egypt via extraction of local as well as imported oilseed covers

Corresponding Author: Mona El-Hamidi, Fats and Oils Department, National Research Centre, 33 Buhouth St. Dokki, Giza, Egypt. Email: mona32001@hotmail.com 
$2 \%$ only of the consumption needs of edible oil. The remaining $98 \%$ has been covered through imported oils either in a refined, bleached and deodorized grade (RBD) or as a semi-refined grade. These oils include soybean oil, sunflower oil, corn oil and palm oil. Table 2 (Aswaq Financial Co., 2018) lists the quantities imported of these four oils during recent years.

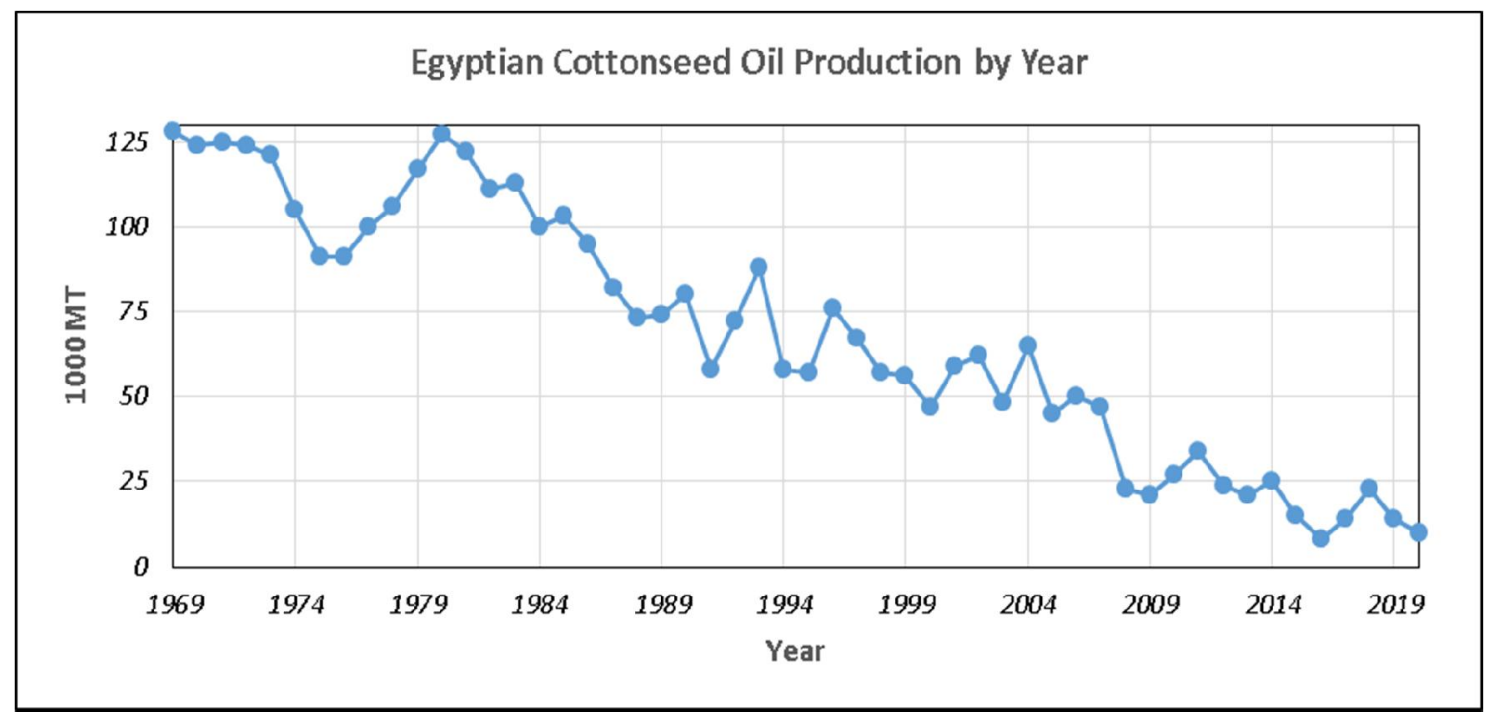

Fig. 1: Cottonseed oil production per year

Table 1: Egypt's imports of soybeans.

\begin{tabular}{cc}
\hline Year & Total quantities imported from soybean seed (tons) \\
\hline $\mathbf{2 0 1 5}$ & 1.892 .555 \\
$\mathbf{2 0 1 6}$ & 1.549 .412 \\
$\mathbf{2 0 1 7}$ & 2.137 .713 \\
$\mathbf{2 0 1 8}$ & 3.342 .223 \\
\hline
\end{tabular}

Table 2: Quantities of various vegetable oils imported by Egypt from 2015 to 2018 in ton).

\begin{tabular}{lccccc}
\hline Year & Soybean oil & Sunflower oil & Palm oil & Corn oil & Total \\
\hline $\mathbf{2 0 1 5}$ & 442.565 & 266.459 & 851.576 & 43.932 & 1.604 .532 \\
$\mathbf{2 0 1 6}$ & 717.978 & 308.647 & 856.517 & 54.878 & 1.938 .020 \\
$\mathbf{2 0 1 7}$ & 227.320 & 467.334 & 948.022 & 20.511 & 1.663 .187 \\
$\mathbf{2 0 1 8}$ & 145.200 & 448.316 & 950.938 & 48.503 & 1.592 .957 \\
\hline
\end{tabular}

It is clear that palm oil is the major oil imported by Egypt whereby it represents about $60 \%$ of total imported oils in 2018 while the quantity imported from corn oil is the least being about $3 \%$ in the same year. Palm oil is imported from Indonesia and Malaysia after being refined, bleached and deodorized (RBD). The amount of palm oil imported from Indonesia represents $96 \%$ of total imported palm oil. This RBD grade palm oil usually develops free fatty acids during transportation which makes it in need of extra refining process to remove these free acids.

It can be also noticed that the imported quantity of soybean oil has been reduced markedly in recent years due to the increase in the solvent extraction capacity of local plants fed with imported soybean.

\section{Processing steps for edible oil production from oilseed}

In brief, the main processing steps followed to produce edible oil from oilseed include extraction of the crude oil from its seeds and then refining of the crude oil to make it suitable for human consumption. The extraction can be made mechanically using hydraulic presses or screw presses. It can be carried out also by solvent extraction using commercial hexane. The latter technology is the most commonly used as the oil yield is higher than the mechanical extraction. The refining of the crude oil is usually done in several consecutive steps. These include the removal of 
free fatty acids either using alkaline sodium hydroxide or physically by distilling off the free acids at high temperature under vacuum. The choice of the suitable technology to be adopted depends on the type of crude oil. For example, alkali refining is more suitable with crude cottonseed oil while physical refining is more suitable with soybean oil and palm oil. The next refining step is the treatment of the oil produced from the pre-mentioned step as to remove the coloring matters using suitable bleaching earth, usually bentonite clay. The final step is the removal of the undesirable odor from the bleached oil in deodorization towers at high temperature under vacuum. Each of the prementioned processing steps is carried out via several additional steps in the industrial plants including the extraction plant, the refining plant, the bleaching plant and the deodorization plant.

\section{Important parameters for successful edible oil industry}

No doubt that careful adjustment and control of operating and design conditions of each processing step is the key for any successful industry. As pre-mentioned, in case of edible oil industry, these processing steps include the steps of crude oil extraction from oilseed, removal of free acids by chemical and physical methods, de-colorization of neutralized oil using bleaching earth and the step of deodorizing the bleached oil.

The effect of the operating and design conditions on the efficiency of each process is outlined below:

\subsection{Extraction of crude oil from oilseed}

The extraction of crude oil may be carried mechanically using screw press or hydraulic press or by direct solvent extraction using commercial hexane or using both technologies in what is called prepress solvent extraction. Residual oil in extracted meal is lowest in case of direct solvent extraction and highest in case of hydraulic press. Therefore it is recommended to extract oilseed low in oil content such as cottonseed using solvent extraction technology rather than mechanical extraction. In case of oilseed rich in oil content such as canola oil, mechanical extraction is more preferred since oilseed rich in oil could not be flaked prior to solvent extraction. This step is an essential step to increase surface area and to facilitate solvent diffusion into the cell walls which improve the extraction efficiency. Although oil extraction using screw presses yields more oil than hydraulic pressing, the protein of the extracted meal could be denatured by the overheating developed in the screw press during its operation. Therefore, oil extraction using screw presses is not recommended if the meal will be used as a source of good quality protein.

The efficiency of solvent extraction process is determined by the design characteristics of the extractor as well as the other operating conditions such as the rate of solvent fed to the extractor compared to the rate of oilseed meat. It also depends on the efficiency of the mechanical and heating pretreatment steps of oilseed prior to extraction including the flaking of ground oilseed and their cooking. Thickness of oilseed flakes and the temperature as well as humidity during the cooking step are quite important factors. On the other hand, the efficiency of oil extraction by hydraulic pressing depends on the pressure applied in the hydraulic press.

\subsection{Neutralization of free fatty acids in extracted crude oil}

Regarding the alkali refining plant, the process is made through several steps whereby the crude oil is first mixed in a suitable mixing unit with caustic soda solution of proper concentration and in an amount sufficient to remove free fatty acids in the crude oil. It results in the formation of two products being the refined oil and dark mucilage containing the saponified fatty acids, gummy substances and oil pigments. The mucilage collected down the refined oil will be then separated from the refined oil as a byproduct. The mucilage is then treated with excess caustic soda solution to complete the saponification of the oil entrained in the mucilage. The product is then called soap stock, which can be utilized for production of fatty acids in fatty acid production plant as will be explained later or for the production of low-grade soap. The refined oil is then washed with water and the washing water will be then separated from the refined oil.

Although the process seems to be simple but it requires careful control of the concentration and amount of caustic soda used, efficient separation of mucilage from the refined oil and efficient separation of refined oil from washing water. Separation can be done either by gravity settling or by centrifuging at controlled speed which is more efficient. Inefficient separation of oil from mucilage 
results in an increased losses of oil. Also, inefficient separation of oil from washing water will lead to increased oil losses and increased biological load of waste washing water from the washing unit. The latter has a negative impact on the environment and it may increase the need for waste water treatment unit of large capacity (Abou El-Elela and Zaher, 1998).

\subsection{The fatty acid production plant}

The first step in this plant is the treatment of mucilage with caustic soda to saponify the oil entrained in the mucilage to give what is called soap stock. The latter will be then acidulated using sulfuric acids as to split the fatty acids back which is produced as crude grade fatty acids. The latter will be then fed to a distillation unit where a refined grade fatty acids are produced.

However, if the saponification of mucilage to give soap stock is incomplete, some of the residual oil entrained in the soap stock will be left in the produced crude fatty acids. Since the oil is much less volatile than fatty acids, it does not distill together with the fatty acids and it rather accumulates in the bottom of the fatty acid distillation tower. By time, it polymerizes and the formed thick polymer adheres to the heating element in the distillation tower which greatly reduces its heating efficiency. This markedly reduces the efficiency of the distillation process of fatty acids and it necessitates, in most cases, the stopping of the fatty acid purification unit whereby the heating element in the distillation tower is maintained back.

\subsection{The plant designed for the bleaching of neutralized oil}

In this plant, the neutralized oil is heated, stirred for a certain period with suitable bleaching earth which adsorbs the coloring matters from the oil. The bleached oil is then filtered from spent bleaching earth in special filters. Use of inefficient filters may result in increased oil losses in the spent earth and/or contamination of bleached oil with some entrained fine particles of used earth. The efficiency of the bleaching process is determined also by the type of clay used and its load, the bleaching temperature and the speed as well as period of stirring. It should be emphasized that different types of clays may have different adsorption capacity for different types of pigments (ElNoamany et al., 2014). Oils rich in carotenoids may need a certain type of clay, which is not suitable for oils rich in chlorophyll pigment. Therefore, the type of bleaching earth to be used should be carefully chosen.

The spent clay usually contains about $25 \%$ of its weight oil. This spent clay should be regularly removed from the industrial site and disposed in the desert. There is a fire risk by its self-ignition during their storage for long time. It could rather be utilized as an amendment of sandy soil.

\subsection{The deodorization plant}

In this plant, bad odor is removed from the bleached oil by distilling such odor at high temperature under vacuum in big distillation towers provided with direct and indirect steam. Huge quantities of cooling water is commonly used in direct contact with the volatiles. Usually the volatiles contain some short chain fatty acids, which condense in the cooling water delivered to a certain receiving unit called hot well. The water collected in the hot well is then delivered to huge cooling towers whereby it is cooled back by strong air streams blown from powerful air blowers and is then recirculated in the deodorization unit. However, it may happen that fatty acids condensed in the cooling water block the blowers whereby its operation efficiency is greatly reduced. Thus, the temperature of the recirculated water will not be low enough to condense the volatiles in the deodorizer. This in turns have negative effect on the efficiency of the distillation process in the deodorizer. Mechanical skimmers are, therefore, highly recommended to skim and remove the condensed fatty acids floating on the water surface in the hot wells (Abou El-Elela and Zaher, 1998).

In addition to the effect of process conditions, the period and the conditions of oilseed storage prior to extraction as well as the period and storage conditions of the extracted crude oil before being refined may influence the produced oil quality. For example, crude cottonseed oil contains yellow acidic gossypol as a major pigment, which can be removed during alkali refining step. However, if the seeds are stored for long period especially in an area not well ventilated, gossypol undergoes chemical conversion to a much darker non acidic new form (El-Nokrashy et al. (1976) and Osman et al. (1976). Such conversion may also happen during long storage periods of crude cottonseed oil prior to refining. This new non acidic form of dark pigment resists removal by conventional alkali treatment 
and the refined oil is usually quite dark. This necessitates the use of excess alkali and excess bleaching earth to reduce the oil color to the standards acceptable by the consumer. This results in increased oil losses and hence increased costs.

\section{Companies established in Egypt for oilseed extraction}

Several companies have been established in Egypt to produce edible oils from oilseed. Some of these companies belong to the public sector while others belong to the private sector. Tables 3 and 4 give a list of these companies showing their locations and operating capacities. Some other companies for oilseed extraction have been designed and still under construction in Egypt. These are listed in Table (5).

Table 3: Companies in Egypt designed for oilseed extraction and belong to the public sector.

\begin{tabular}{lcclll}
\hline The Company's name & $\begin{array}{c}\text { Operating } \\
\text { capacity } \\
\text { Ton } \\
\text { oilseed/Day }\end{array}$ & \multicolumn{1}{c}{ Location } & $\begin{array}{c}\text { Extraction } \\
\text { technology }\end{array}$ & $\begin{array}{c}\text { The } \\
\text { supplying } \\
\text { company }\end{array}$ & Origin \\
\hline $\begin{array}{l}\text { Alexandria Oils and } \\
\text { Soap }\end{array}$ & 200 & Kafr El Zayat city & Solvent extraction & De Smet & Belgium \\
\hline Egyptian salt and soda & 200 & Kafr El Zayat city & Solvent extraction & De Smet & Belgium \\
\hline $\begin{array}{l}\text { Extracted oils and their } \\
\text { products }\end{array}$ & 300 & Damanhur city & Solvent extraction & De Smet & Belgium \\
\hline Tanta oils and soaps & 300 & Tanta / Banha cities & Solvent extraction & De Smet & Belgium \\
\hline Egypt Oil and Soap & 200 & $\begin{array}{l}\text { Sandoub city, } \\
\text { Mansoura city }\end{array}$ & Solvent extraction & De Smet & Belgium \\
\hline \begin{tabular}{l} 
Cairo Oils and Soap \\
\multicolumn{1}{c}{ Oils and }
\end{tabular} & 200 & $\begin{array}{l}\text { Badrashin, Cairo } \\
\text { city }\end{array}$ & Solvent extraction & De Smet & Belgium \\
\hline $\begin{array}{l}\text { Nile } \\
\text { Detergents }\end{array}$ & 400 & $\begin{array}{l}\text { Bani Qara, Sohag } \\
\text { city }\end{array}$ & Solvent extraction & De Smet & Belgium \\
\hline $\begin{array}{l}\text { Nile for ginning cotton } \\
\text { Total }\end{array}$ & 200 & Minya city & Solvent extraction & De Smet & Belgium \\
\hline
\end{tabular}

Table 4: Companies in Egypt designed for oilseed extraction and belong to the private / investment sector.

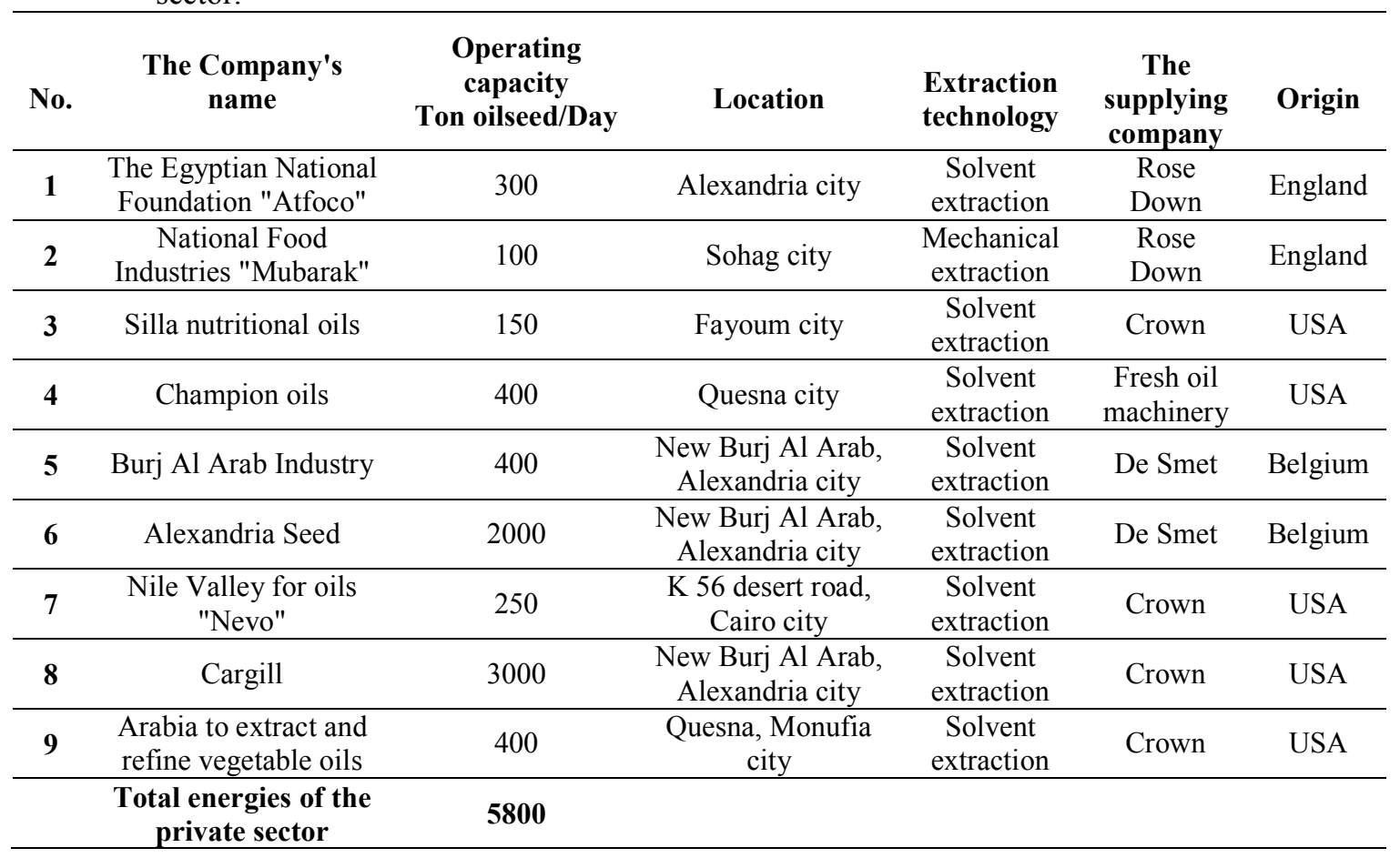


Table 5: Companies in Egypt designed for oilseed extraction and still under construction

\begin{tabular}{|c|c|c|c|c|c|c|}
\hline No. & $\begin{array}{c}\text { The Company's } \\
\text { name }\end{array}$ & $\begin{array}{c}\text { Operating } \\
\text { capacity } \\
\text { Ton } \\
\text { oilseed/Day }\end{array}$ & Location & $\begin{array}{l}\text { Extraction } \\
\text { technology }\end{array}$ & $\begin{array}{l}\text { The } \\
\text { supplying } \\
\text { company }\end{array}$ & Origin \\
\hline 1 & $\begin{array}{c}\text { Alexandria for } \\
\text { oilseed }\end{array}$ & 3000 & $\begin{array}{l}\text { Burj Al Arab, } \\
\text { Alexandria city. }\end{array}$ & $\begin{array}{l}\text { Solvent } \\
\text { extraction }\end{array}$ & De smet & Belgium \\
\hline 2 & $\begin{array}{c}\text { National Oil } \\
\text { Company } \\
\text { (Cargill + ADM) }\end{array}$ & 3000 & $\begin{array}{l}\text { Burj Al Arab, } \\
\text { Alexandria city }\end{array}$ & $\begin{array}{l}\text { Solvent } \\
\text { extraction }\end{array}$ & De smet & Belgium \\
\hline 3 & $\begin{array}{l}\text { Burj Al Arab to } \\
\text { extract vegetable } \\
\text { oils }\end{array}$ & 600 & $\begin{array}{l}\text { Burj Al Arab, } \\
\text { Alexandria city }\end{array}$ & $\begin{array}{l}\text { Solvent } \\
\text { extraction }\end{array}$ & Kumar & India \\
\hline 4 & $\begin{array}{l}\text { International } \\
\text { Oilex }\end{array}$ & 500 & Sadat city, Cairo city & $\begin{array}{l}\text { Solvent } \\
\text { extraction }\end{array}$ & Kumar & India \\
\hline 5 & $\begin{array}{l}\text { International } \\
\text { Oilex }\end{array}$ & 3000 & Sadat city, Cairo city & $\begin{array}{l}\text { Solvent } \\
\text { extraction }\end{array}$ & De smet & Belgium \\
\hline 6 & Almagd & 500 & Sadat city, Cairo city & $\begin{array}{l}\text { Solvent } \\
\text { extraction }\end{array}$ & Kumar & India \\
\hline 7 & Almagd & 2000 & $\begin{array}{l}6 \text { October city, Giza } \\
\text { city }\end{array}$ & $\begin{array}{l}\text { Solvent } \\
\text { extraction }\end{array}$ & De smet & Belgium \\
\hline 8 & Modern oils & 750 & Sadat city, Cairo city & $\begin{array}{l}\text { Solvent } \\
\text { extraction }\end{array}$ & Myande & $\begin{array}{l}\text { India / } \\
\text { China }\end{array}$ \\
\hline 9 & $\begin{array}{l}\text { Al-Ahram } \\
\text { Poultry }\end{array}$ & 500 & Sadat city, Cairo city & $\begin{array}{l}\text { Solvent } \\
\text { extraction }\end{array}$ & Instabro & USA \\
\hline 10 & Al-Reda & 600 & Sadat city, Cairo city & $\begin{array}{l}\text { Solvent } \\
\text { extraction }\end{array}$ & Kumar & India \\
\hline 11 & Kinana & 300 & $\begin{array}{l}6 \text { October city, Giza } \\
\text { city }\end{array}$ & $\begin{array}{l}\text { Solvent } \\
\text { extraction }\end{array}$ & Kumar & India \\
\hline 12 & Al-Safa & 300 & $\begin{array}{l}\text { Assad village, desert } \\
\text { road, Alexandria city }\end{array}$ & $\begin{array}{l}\text { Solvent } \\
\text { extraction }\end{array}$ & Kumar & India \\
\hline 13 & Al-Safa & 1000 & $\begin{array}{l}\text { Assad village, desert } \\
\text { road, Alexandria city }\end{array}$ & $\begin{array}{l}\text { Solvent } \\
\text { extraction }\end{array}$ & Kumar & India \\
\hline 14 & Nile Valley & 500 & $\begin{array}{l}\text { Motobus, Kafr El } \\
\text { Sheikh City }\end{array}$ & $\begin{array}{l}\text { Solvent } \\
\text { extraction }\end{array}$ & Kumar & India \\
\hline 15 & Amgad & 500 & $\begin{array}{l}\text { Motobus, Kafr El } \\
\text { Sheikh City }\end{array}$ & $\begin{array}{l}\text { Solvent } \\
\text { extraction }\end{array}$ & Kumar & India \\
\hline 16 & Al-Italia & 300 & $\begin{array}{l}\text { Motobus, Kafr El } \\
\text { Sheikh City }\end{array}$ & $\begin{array}{l}\text { Solvent } \\
\text { extraction }\end{array}$ & Kumar & China \\
\hline 17 & Cairo Three M & 500 & $\begin{array}{l}\text { Baltim, Kafr El } \\
\text { Sheikh City }\end{array}$ & $\begin{array}{l}\text { Solvent } \\
\text { extraction }\end{array}$ & Kumar & India \\
\hline \multirow[t]{2}{*}{18} & Acma & 1000 & $\begin{array}{l}\text { The road to Khanka, } \\
\text { Cairo city }\end{array}$ & & Myande & China \\
\hline & Total & 18850 & & & & \\
\hline
\end{tabular}

\section{Conclusion and Recommendations}

Regular industrial and environmental auditing of all edible oil processing units in Egypt are highly recommended as to minimize environmental pollution due to this industry and to improve the production efficiency. The production efficiency can be improved via the decrease in wastes and losses, the decrease in production expenses as well as the production of oil of better quality. All these can be achieved by process modifications suggested by experts in edible oil processing technology in accordance to the result of the industrial and environmental audits.

\section{References}

Abou El-Elela, S.I., and F.A. Zaher, 1998. Pollution Prevention in the Oil Soap and industry: A Case Study. Water Science and Technology, 38:139-144. 
https://www.sciencedirect.com/science/article/abs/pii/S0273122398005228 https://doi.org/10.1016/S0273-1223(98)00522-8

Aswaq Financial Co. Analysis Report of, 2018. On the Strategic Commodities Market in Egypt; (24/1/2019). Provided by Engineer Atteia Shaaban, Consultant for Extraction \& Refining of Edible Oils; Vice-President of Oils \& Oils by-Products Division; Chamber of Food Industry; Federation of Egyptian Industry.

Source: http://www.aswaqfinancial.com/index.php

El-Hamidi, M., and F.A. Zaher, 2018. Production of Vegetable Oils in the World and in Egypt: an Overview. Bulletin of the National Research Centre, 42:19.

https://bnrc.springeropen.com/articles/10.1186/s42269-018-0019-0

https://doi.org/10.1186/s42269-018-0019-0

El-Noamany, H.M., O.A. Megahed, and F.A. Zaher, 2014. Comparison between Different Types of Common Adsorbents: part II: Adsorption Capacity to Remove Carotenoids as Compared to Chlorophyll Pigment. The Transactions of the Egyptian Society of Chemical Engineers (TESCE) 4:16-28. ISSN: 1012-6007

https://journals.indexcopernicus.com/search/details?id=37526

El-Nokrashy, A.S., F.A. Zaher, and F. Osman, 1976. Cottonseed Color Fixed Pigments. Part I. Selectivity of Hexane Isomers. Die Nahrung, 20: 117-124.

https://onlinelibrary.wiley.com/doi/abs/10.1002/food.19760200202

DOI: $10.1002 /$ food.19760200202

Nahrung. 1976. 20 (2):117-24. doi: 10.1002/food.19760200202.

Jennings, B., 2010. Dr. Otto's Amazing Oil.

Source: http://pabook2.libraries.psu.edu/palitmap/Cottonseed.html

Osman, F., F.A. Zaher, and A.S. El-Nokrashy, 1976. Cottonseed Color Fixed Pigments, Part II: Role of Hexane Isomers on Oil Quality. Die Nahrung.20: $475-482$.

https://pubmed.ncbi.nlm.nih.gov/989157/ DOI: 10.1002/food.19760200503

Nahrung, 1976. 20 (5):475-82. doi: 10.1002/food.19760200503.

United States Department of Agriculture, 2020. Source: (https://www.usda.gov). https://www. indexmundi.com /agriculture/?country=eg\&commodity=cottonseed-oil\&graph=production 